\title{
TÜRKÜLERİN ORTAOKUL TÜRKÇE DERSLERİNDE KULLANIMI VE İŞLEVLERI
}

\section{THE ROLE AND THE USE OF FOLK SONGS IN TURKISH LANGUAGE EDUCATION OF SECONDARY SCHOOL}

\section{ИСПОЛЬЗОВАНИЕ И ОСОБЕННОСТИ ПРЕПОДАВАНИЯ ТУРЕЦКОГО ЯЗЫКА В ТУРЕЦКИХ ШКОЛАХ СРЕДНЕГО УРОВНЯ ОБРАЗОВАНИЯ ${ }^{1}$}

\author{
Bülent ARI* \\ Mustafa Burak TOP ${ }^{* *}$
}

\section{ÖZ}

Halk bilimi ürünlerinin eğitimde kullanılması, çocukların sözcük dağarcığını genişletmeye ve öğrencilere kültür aktarımının gerçekleştirilmesine katkı sağlamaktadır. Bu bakımdan halk bilimi ürünlerinden türkülerin de önemli bir işlevi vardır. Yapılan çalışmada Milli Eğitim Bakanlığı'nın 2015-2016 öğretim yılı ilköğretim ders kitapları listesinde 5-8. sınıflarda okutulacak olan Türkçe ders kitapları incelenmiştir. Bu kitaplardan Cem Yayınları Türkçe 5. sınıf ders kitabında yer alan "Sözlü Geleneğimiz" başlıklı metin içinde bulunan Çanakkale Türküsü ile Meram Yayınları Türkçe 7. sınıf ders kitabında bulunan "Kişisel Gelişim" temasında bir serbest okuma metni olarak yer alan "Koşma" örneği incelenmiştir. Bununla birlikte Çanakkale Türküsü' nün bulunduğu metin ile ilgili etkinlikler ele alınmış ve "Koşma" adlı şiir ile örnek bir türkü olarak "Demirci Mehmet Efe” türküsü için 2015 Türkçe Öğretim Programı'ndaki kazanımlar doğrultusunda örnek etkinlikler hazırlanmıştır. Bunun yanında bu türkülerde yer alan değerler incelenmiştir. Araştırmanın sonucunda Türkçe öğretim programında yer alan kazanımların gerçekleştirilmesinde ve değer aktarımında türkülerin kullanılabilecek materyaller olabileceği ifade edilmiştir.

Anahtar Kelimeler: Türküler, Eğitim, Türkçe Öğretimi, Kültürel Değerler, Türkçe Öğretim Programı

\section{ABSTRACT}

Making use of folk traditions in education contrubates to one's vocabulary and passes the traditions on to new generations. Therefore folk songs have an important function. In this article we examined Ministry of National Education's textbooks which are set to be used from 5th grade to 8th grade in 2015-2016 school years.

The folk song Çanakkale Türküsü under the title oral tradition placed in the textbooks for 7 thgrades published by Meram publication hause are examined as examples. In addition

${ }^{1}$ DOI : $10.17498 /$ kdeniz.513

* Mustafa Kemal Üniversitesi, Eğitim Fak. Türkçe Eğitimi Bölümü, bulentari01@gmail.com, Doç. Dr. Hatay.

** Mustafa Kemal Üniversitesi Eğitim Fak., İlköğretim Bölümü , mburaktop@gmail.com, Arş. Gör. Hatay. 
to this we surveyed a bunch of activities that Çanakkale Türküsü involved with. And also some representative activities based on the folk poem "Koşma" anda folk song called "Demirci Mehmet Efe" are prepared in the direction of the goals made in Turkish Language Education Program. Furthermore we traced Turkish cultural values in these folk songs.

As a result it is suggested in the article that folk songs can be utilized in order to accomplish the goals made in Turkish language education programs and can be utilized to pass the cultural values on to new generations.

Key Words: Folk songs, Education, Turkish Language Education, Values of Culture, Turkish Language Teaching Program

\section{АННОТАЦИЯ}

В целях расширения словарного запаса детей и формирования культуры речи необходимо внедрять элементы фольклора. Знание и использование устного народного творчества турок имеет огромную роль. Данная работа основывается на анализе учебников 5-8 класса по турцекому языку, утвержденных программой Министерства образования Турции на 2015-2016 учебный год. Предметом анализа послужили следующие тексты учебников по турецкому языку: 5 класс в разделе под заглавием «Особенности устного народного творчества» песни Чанаккале и тексты Мерама, 7 класс в разделе «Развитие личности» текст для внеклассного чтения «Бег». Также образцом для анализа послужила песня «Кузнец Мехмет Эфе», которая в 2015 году была одобрена Учебной программой по турецкому языку. Вместе с этими произведения были проанализированы другие тексты. В результате турецкие песни, которые были одобрены учебной программой по турецкому языку были тшательно исследованы.

Ключевые слова: песни, обучение, обучение по турецкому языку, культурные ценности, Учебная программа по турецкому языку.

\section{GIRIŞ:}

Her toplum kendine özgü değerlere sahiptir. Halk kültürü ürünleri de bir millete ait kültürel değerleri içermektedir. Türk Halk kültürü yüzyıllarca süregelen bir süreçte şekillenmiştir. Türk halk kültürü köklerini tarihin derinliklerinden ve çok geniş bir coğrafyadan alan çok zengin bir yapıya sahiptir (Artun, 1999). Yüzyıllarca deneyimler sonucu oluşan ve halkın yaşayışını, değerlerini yansıtan kültürel öğelerin, gelecek nesillere aktarımı ve devamı, toplumların milli benliklerini kaybetmeden devamını sağlaması için oldukça önemlidir. Bu bağlamda kültürel öğelerin korunması ve aktarılmasında eğitim de önemli bir süreçtir.

Halk edebiyatı ürünleri, çocukların anadilindeki söz varlığını geliştirmesine katkıda bulunur. Dildeki sözcükler, deyimler, söz kalıpları, özdeyiş ve atasözleri, halk edebiyatı ürünleri kullanılarak çocuklara öğretilebilir. Bununla birlikte bu durumun çocuklardaki dil bilinci ve ulus bilincini güçlendirmeye katkı sağlayabileceği ifade edilebilir (Artun, 2009: 6). Bu anlamda halk kültürünün farklı ürünlerinin bu amaçla kullanılabileceğine yönelik araştırmalar mevcuttur.

Kültürel öğeleri yansıtan halk kültürü ürünlerinin eğitime yansımasını belli alanlarda görebilmekteyiz. Ninnilerin çocuklar üzerinde eğitim amaçlı kullanılabilen halk kültürü öğeleri olduğunu belirten çalışmalar bulunmaktadır (Toker, 2011; Demir, 2008). Bu 
çalışmalarda ninnilerin çocukların özellikle anadil öğretiminde faydalı olduğu ifade edilmiştir. Ninnilerde çocuklara farklı alanlarda birçok kelime ve kavramın öğretildiği vurgulanmıştır.

Toker çalışmasında toplumsal değerlerin ninniler aracılığıyla çocuklara aktarıldığını belirtmiştir.

"Bahçelerden su gelir

Tekkelerden hu gelir

Yavrum yattı beşiğe

Şimdi uykusu gelir." (Artun 1989: 11'dan Akt: Toker, 2011: 26).

Tekerlemelerin eğitimde kullanımına yönelik çalışmalar da bulunmaktadır (Toker, 2011; Kurudayığlu, 2012).Toker (2011) halk kültürü ürünlerinden olan tekerlemelerde ölçü ve uyak kavramlarının çocuklara öğretildiğini, aynı zamanda tekerlemelerin çocukların telaffuz ve akıcı konuşmalarına yardımcı olduğunu ifade etmiştir.

Sözlü edebiyat ürünlerinden olan bilmecelerin de çocukların eğitiminde önemli olduğuna yönelik çalışmalar yer almaktadır. Yangil ve Kerimoğlu (2014), bilmecelerin çocukların zihinsel gelişimine büyük katkısı olduğunu ifade etmiştir. Bununla birlikte bilmecelerin içinde çeşitli söz sanatlarına ve imgelere yer verildiğini ve bu durumun öğrencilerin problem çözme ve yaratıcı düşünme becerilerini geliştirmesine katk1 sağlayacağını ifade etmiştir.

Bilmeceler aracılığıyla kültürümüzün özellikleri çocuklara hissettirilebilir. Bilmeceler, dil boyutunda öğrencilerin kelime hazinesini zenginleştiren, kavram öğretimine yardımcı olan ve kelimeleri doğru telaffuz edebilmelerine yardımcı olan; düşünme boyutunda ise öğrencilerin yaratıcı düşünme, eleştirel düşünme ve problem çözme becerilerinin çerçevesini çizecek olan ürünlerdir (Balta, 2013: 893-894).

Bulut (2013) yaptığı çalışmada atasözü ve deyimlerin de kültür aktarımında önemli bir işlevi olduğunu; iyiyi, güzeli, doğruyu, adaleti ortaya koyduğunu ifade etmiştir. Atasözlerinin ve deyimlerin çocukların ifade etme becerilerini ve muhakeme yeteneklerini geliştireceğini; milli dil bilinci ve milli şuur oluşturacağını; çocukların sözcük varlığının zenginleşmesine olumlu etkisi olacağını belirtmiştir. Bu anlamda atasözleri ve deyimlerin Türkçe öğretiminde kullanılmasının faydalı olacağını ifade etmiştir.

Yabancı dil öğretiminde kullanılan araç-gereçler büyük önem taşımaktadır ve yabancı dil öğretiminde kültürel unsurların da incelenmesi gerekmektedir. Bir dilin yabancı dil olarak öğretimi için hazırlanan kitaplarda dilin kullanımı, ses bilgisi, kelime bilgisi öğrenmenin yanı sıra iletişim kurmak amacıyla o dilin konuşulduğu toplumun kültürel değer ve normlarının da yer aldığı görülmektedir. Çünkü kültür kavramı, bir toplumun dilini öğrenen kişilerin o topluma ait somut ve soyut değerlerini yaşamla ilişkilendirmelerini sağlar (Tüm ve Sarkmaz, 2012: 448).

Yapılan çalışmalarda halk kültürü ürünlerinin eğitimde kullanılmasının birçok faydası olduğu görülmektedir. Türküler de tarihten gelen kültürel unsurları taşıyan halk ürünleri olduğundan dolayı türkülerin de eğitimde kullanılması toplumda nesiller arasında kültür akışı için faydalı olabilecek bir durumdur.

Türkü en yalın tanımıyla, ezgi ile söylenen Türk halk şiirleridir (Vural, 2011: 398).

Halk şiiri musiki ile söylendiğinde "türkü” adını almaktadır. Türküler, dünya milletlerinde zamanla kaybolan, fakat Türk milletinde yaşamaya devam eden bir gelenektir. Kayserili bağlama üstadı Şemsi Yastıman türkü için "Türkü milletimizin her şeyidir. 
Güzellikleri canlı olarak ortaya koyarken, çirkinlikleri iğneli bir biçimde alaya alarak sevinci hareketle hüznü dramatize ederek dile getirir" demiștir. Bu anlamda türkülerimiz milletimizi millet yapan önemli unsurlardan biri olarak kabul edilebilir (Özsoy, 2004: 113).

Türküler hayatımızda her an olması nedeniyle hayatımızın vazgeçilmez bir parçası olarak kabul edilmektedir. Türk insanı acı, sevinç, hasret, gurbet vb. duygularını türküler ile dile getirmiştir. Yani Türk insanı türkülerle konuşmuş, türkülerle dertleşmiş, türkülerle hasret gidermiş ve acılarını, sevinçlerini türküler aracılığıyla ifade etmiştir. Bu anlamda türküler iletişim aracı olmanın yanında her bir sözünde bir anlam barındırmaktadır ve kullanılan bu kavramlar hiçbir zaman türkülerde gelişigüzel yer almış kavramlar değillerdir (Aytaş, 2003). Bu bağlamda, türkülerin tarih boyunca içinde bulunduğu coğrafyada yaşayan insanların yaşamları, kültürleri, duyguları hakkında bilgi veren bir halk kültürü ürünü olduğu söylenebilir.

Türküler, çeşitli duygu ve durumları ifadesinin yanında, tarihsel olaylar, sosyoekonomik şartlar, kültürel değişimler ve toplumsal yönelimleri de yansıtan bir özellik göstermektedir. (Göher, 2010: 173' den akt: Vural, 2011: 400). Türküler önemli birer değer taşıyıcısıdır. Topluma ait sosyal değerler, türküler aracılığıyla gelecek kuşaklara aktarılmaktadır. (Başgöz, 2008: 144' den akt: Vural, 2011: 400). Bunun yanında türküler tarihsel olayların detayları hakkında da bizlere bilgi verebilmektedir. (Vural, 2011: 401).

Türküler belli bir dönemde ortaya çıktıktan sonra sözlerinde ve ezgilerinde zamanla değişiklikler olabilmektedir. Türkülerin bazıları zamanla unutulurken toplumda derin bir iz bırakmış olan kahramanlık türküleri, aşk türküleri, tarihi türküler uzun yıllar varlığını koruyabilir (Uğurlu, 2009: 151-152' den akt: Vural, 2011: 401).

Öztürk, (2011) türkülerin psikolojik işlev, estetik işlev, eğlence işlevi, eleştiri işlevi, söylenemeyeni söyleme işlevi, haber verme işlevi, eğitici ve ahlaki işlevler, milli işlev, geleneksel işlev, dini işlev, ritmik işlev (iş başında ya da askerlikte) ve ticari işlev (üretilip satılan bir meta anlamında) gibi birçok işlevinin de olduğunu ifade etmiştir. (Vural, 2011: 400). Ayrıca müzikle dil öğretimi, hem ana dil öğretiminde hem de yabancı dil öğretiminde kullanılmakta olup bu yöntem öğrencileri rahatlatan, dinlendiren ve neşelendiren bir yöntemdir (Çangal, 2012: 12).

Türküler konusuna göre çeşitlilik göstermektedir. Tarihi türküler, yiğitlik ve kahramanlık türküleri, ayrılık ve hasret türküleri, aşk türküleri gibi türküler buna örnek olarak verilebilir. Türkülerin Türkçe öğretiminde kullanılması, hem çocuklara kelime öğretiminde faydalı olabilir hem de türküler ile çocuklara geçmiş döneme dair bilgilerin verilmesi mümkün olur. Tarihi türküler öğrencilere tarihi olayları açıklamakta fayda sağlayarak onların milli bilinç geliştirebilmesine katkı sağlayabilir ve öğrenciler türküler aracılığıyla geçmiş dönemlere ait bilgi sahibi olarak türkülerden çıkarılabilecek değerleri öğrenebilirler. Bunun yanında öğrenciler türküler aracılığıyla, dildeki ses ahengini ve söz sanatlarının anlatıma kattığı anlamları fark edebilirler.

Yapılan bu çalışmada M.E.B’in “2015-2016 Eğitim-Öğretim Yılında Okutulacak İlk ve Orta Öğretim Ders Kitapları” listesinde yer alan ortaokul düzeyindeki Türkçe ders kitapları incelenmiştir. M.E.B. yayınlarına ait 6. Sınıf, 7. Sınıf ve 8. Sınıf Türkçe ders kitapları ile Cem Yayınları 5. Sınıf, Öğün Yayınları 6. Sınıf, Meram Yayınları 7. Sınıf ve Evren Yayınları 8. Sınıf ders kitapları ile öğrenci çalışma kitapları incelenmiştir. Cem Yayınları 5. Sınıf ders kitabında "Değerlerimiz" temasında "Sözlü Geleneğimiz" metninde "Çanakkale Türküsü”, Meram Yayınları 7. Sınıf ders kitabında "Sevgi” temasında "Uçun Kuşlar", kişisel gelişim temasında ise "Koşma" şiirleri serbest okuma metinleri olarak verilmiştir. 
"Uçun Kuşlar" ve "Koşma” şiirleri belirli bir ezgi ile türkü olarak söylenen şiirlerdir. Bu şiirler kitapta serbest okuma metni olarak yer aldığı için ders kitabında ve öğrenci çalışma kitabında bu şiirlerle ilgili etkinlik yer almamaktadır. Çalışmada Çanakkale Türküsü' nün içinde bulunduğu metin ile ilgili öğrenci çalışma kitabındaki etkinlikler incelenmiştir. "Uçun Kuşlar" ve "Koşma" şiirlerinin her ikisinin de 7. Sınıf düzeyinde olması nedeniyle sadece "Koşma" adlı şiir için ve 8. Sınıf kazanımları doğrultusunda örnek bir türkü olarak "Demirci Mehmet Efe Türküsü” için 2015 Türkçe Öğretim Programı kazanımları doğrultusunda etkinlikler hazırlanmıştır. Bunun yanında bu türkülerde yer alan değerler incelenmiştir.

\section{Türkçe Öğretiminde Kullanılabilecek Türkülere Örnekler: ÇANAKKALE TÜRKÜSÜ}

Çanakkale içinde vurdular beni Ölmeden mezara koydular beni

Of gençliğime eyvah

Çanakkale içinde aynalı çarşı

Ana ben gidiyom düşmana karşı

Of gençliğim eyvah

Çanakkale içinde bir uzun selvi

Kimimiz nişanlı kimimiz evli

Of gençliğim eyvah

Çanakkale içinde bir dolu testi

Analar babalar umudu kesti

Of gençliğim eyvah

\section{Etkinlik}

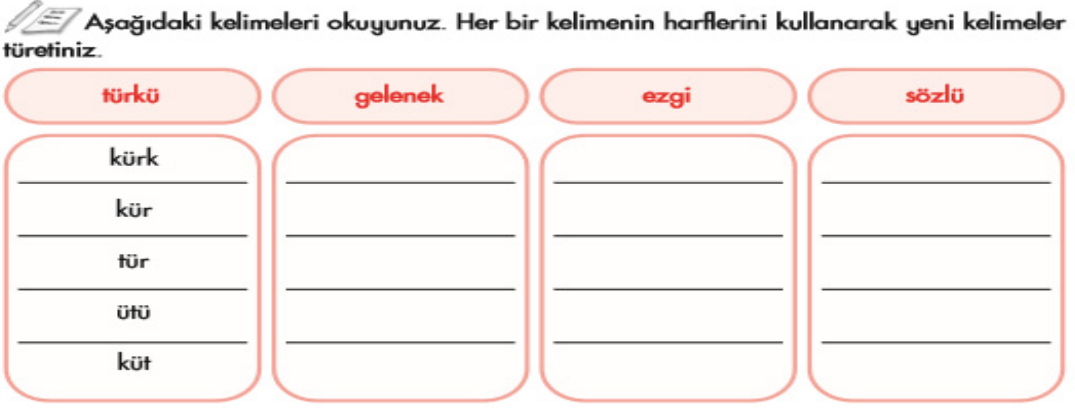




\section{Etkinlik}

$\sum$ Metinde anlatılan türkünün özelliklerini düşünerek bir kavram haritası oluş̧urunuz.

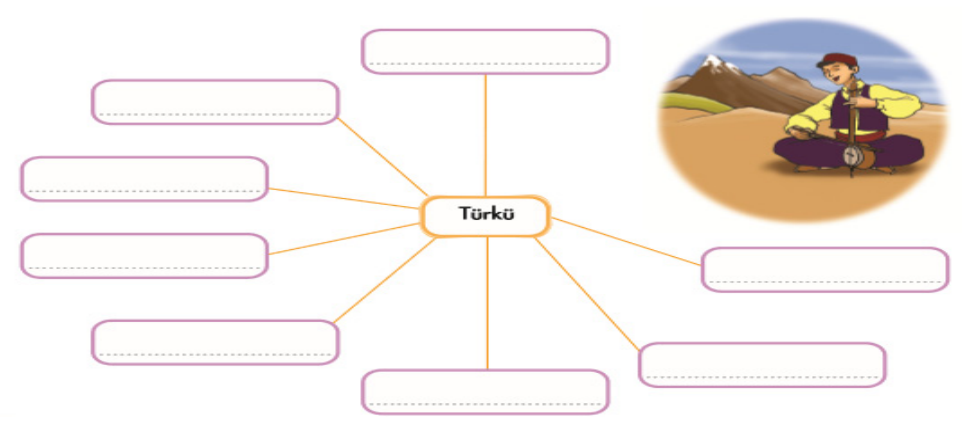

\section{Etkinlik}

\section{Alf Aşăıya metinle ilgili üç soru ve bu soruların cevaplarını yazınız.}

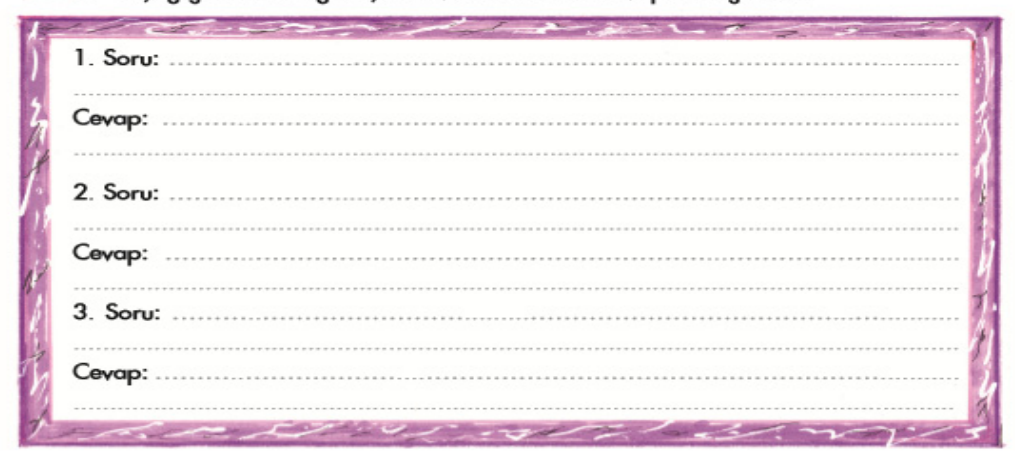

\section{Etkinlik}


bularak yazınız.
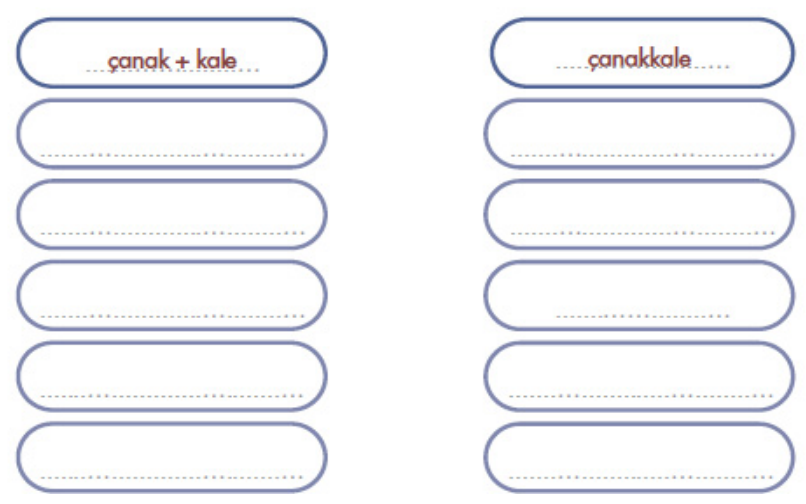


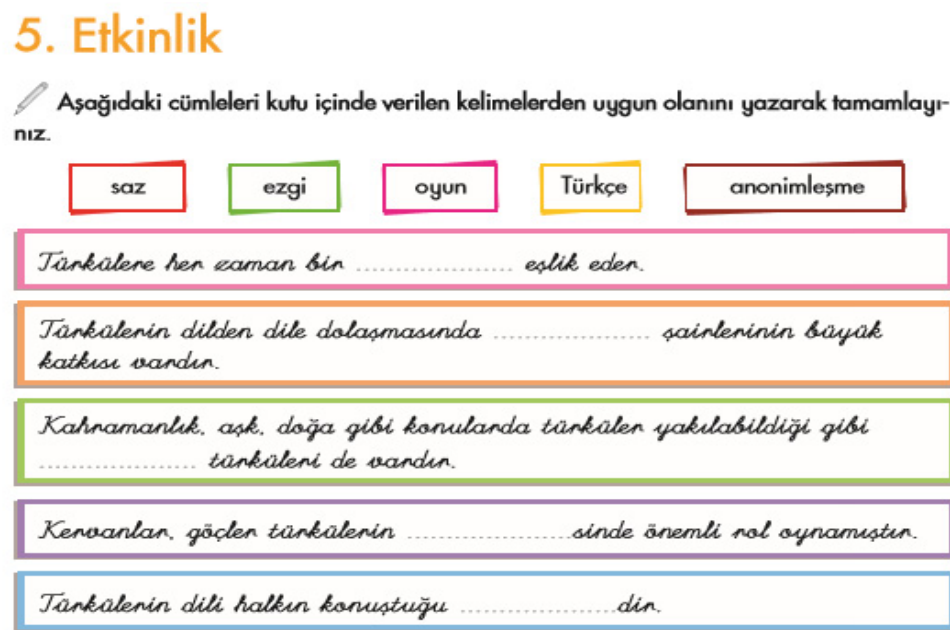

\section{Ełkinlik}

G0 Aşağıdaki resmi inceleyiniz. Düşüncelerinizi yazınız.
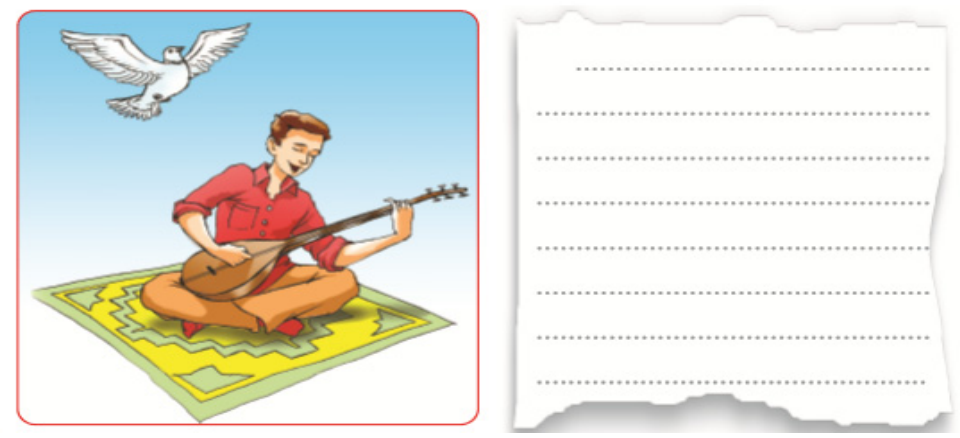

Çanakkale Türküsü 2015-2016 eğitim-öğretim yılında okutulacak kitaplar arasında bulunan Cem Yayınları Türkçe 5. sınıf ders kitabında yer alan "Sözlü Geleneğimiz" başlıklı metin içinde yer almaktadır. Aynı yayınevine ait 5. sınıf öğrenci çalışma kitabında ise metinle ilgili yukarıdaki etkinliklere yer verilmiştir. Bu etkinliklerde öğrencilere kelime ve kavram öğretimi, kavramlar arasındaki ilişkilerin öğretimi amaçlanmaktadır. Kültürel motiflerle yapılan yazma etkinliğinde bu değerlerin öğrencilere tanıtılması hedeflenmektedir.

Bunun yanında Çanakkale Türküsü ile birlikte öğrencilere Çanakkale Savaşı hakkında bilgi verilebilir ve bu etkinlikler tarihi bilgiler ile öğrencilerde milli bilincin oluşmasına katkı sağlayabilir.

\section{KOŞMA}

Dinle sana bir nasihat edeyim

Hatırdan gönülden geçici olma

Yiğidin başına bir iş gelince

Onu yad ellere açıcı olma 
Mecliste arif ol kelamı dinle

El iki söylerse sen birin söyle

Elinden geldikçe sen eylik eyle

Hatıra dokunup yıkıcı olma

Dokunur hatıra kendisin bilmez

Asilzadelerden hiç kemlik olmaz

Sen iylik etde o zayi olmaz

Darılıp da başa kakıcı olma

El arifdir yoklar senin bendini

Dağıtırlar tuzağını fendini

Alçaklarda otur gözet kendini

Kat1 yükseklerden uçucu olma

Muradım nasihat bunda söylemek

Size layık olan onu dinlemek

Sev seni seveni zay'etme emek

Sevenin sözünden geçici olma

Karacaoğlan söyler sözün başarır

Aşkın deryasını boydan aşırır

Seni bir mecliste hacil düşürür

Kötülere konup göçücü olma

Yukarıda yer alan ve belirli biz ezgi ile türkü olarak seslendirilen koşma 2015-2016 eğitim-öğretim yılında okutulacak olan kitaplar arasında bulunan Meram Yayınları Türkçe 7. sınıf ders kitabında yer alan "Kişisel Gelişim" temasında bir serbest okuma metni olarak verilmektedir. Bundan dolayı ders kitabı ve öğrenci çalışma kitabında bu şiir ile ilgili etkinlik yer almamaktadır.

\section{Örnek Etkinlik 1:}

Altı çizili kelimelerin anlamlarını belirterek içinde bu kelimelerin bulunduğu cümlelere yer veriniz.

\section{Örnek Etkinlik 2:}

Nasihat veren atasözlerine üç örnek vererek bu atasözlerini açıklayınız?

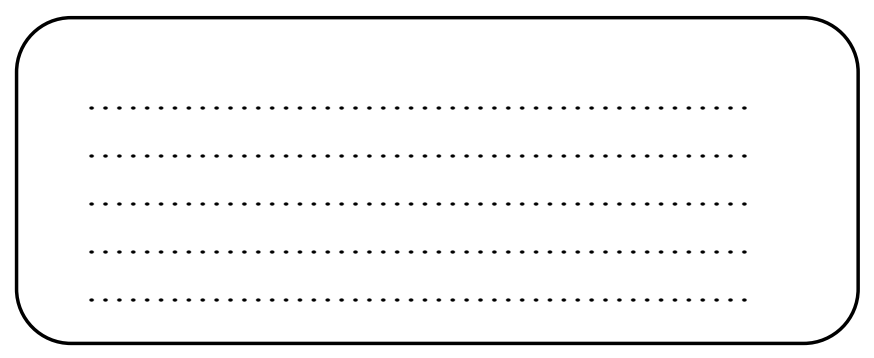




\section{Örnek Etkinlik 3:}

İnsanlar bazen farkında bile olmadan sevdiklerinin gönlünü kırabiliyorlar.

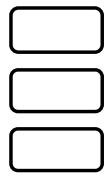

Genel müdürümüz Ahmet Bey, her zaman personeli ile iyi ilişkiler içinde bulunan ve yerli yerinde konuşarak onları hiçbir zaman incitmeyen biriydi.

Nazan, tıp fakültesini kazandıktan sonra hiç kimseyi beğenmeyen, kendini dev aynasında gören biri oldu.

Yukarıdaki cümlelerde yer alan deyimlerin altınız çiziniz. Yukarıdaki şiirde bu deyimlerin anlamları ile ilgili verilmek istenen nasihatin geçtiği dörtlüğü kutucuğa yazınız.

Yapılabilecek benzer etkinlikler öğrencilere kelime öğretiminde kullanılabilir. Bu da 2015 Türkçe Öğretim Programında 7. sınıf kazanımlarında yer alan “Anlamını bilmediği sözcük ve sözcük gruplarının anlamını belirler." ve "Okuduğu metindeki sözcük ve sözcük gruplarının cümle içinde kazandığı anlamı fark eder.” kazanımlarını karşılamaya yönelik olarak kullanılabilir. Ayrıca yapılabilecek benzer etkinlikler "Anlamını bilmediği sözcük ve sözcük gruplarının anlamını belirler." kazanımında yer alan "Sözcükleri öğrenmek için görseller, sözlük, atasözleri ve deyimler sözlüğü vb. araçlar kullanacaktır.” açıklaması doğrultusunda öğrencilere yapılabilecek etkinlikler arasındadır.

Bunun yanında verilen nasihatlerin ileride kendileri için nasıl yardımcı olabileceğini kavramalarına yardımcı olur. Bu bağlamda öğrencilerin atasözleri, deyimler ve özlü sözlerde yapılan nasihatleri dikkate almaları bakımından onlara bir farkındalık oluşturmada katk1 sağlayabilir.

\section{Örnek Etkinlik 4:}

\begin{tabular}{|l|}
\hline Ağlasam sesimi duyar mısınız, \\
Misralarımda; \\
Dokunabilir misiniz, \\
Gözyaşlarıma, ellerinizle? \\
Bilmezdim şarkıların bu kadar güzel \\
Kelimelerinse kifayetsiz olduğunu \\
Bu derde düşmeden önce \\
Bir yer var biliyorum; \\
Her şeyi söylemek mümkün; \\
Epeyce yaklaşmışım duyuyorum \\
Anlatamıyorum \\
\hline
\end{tabular}

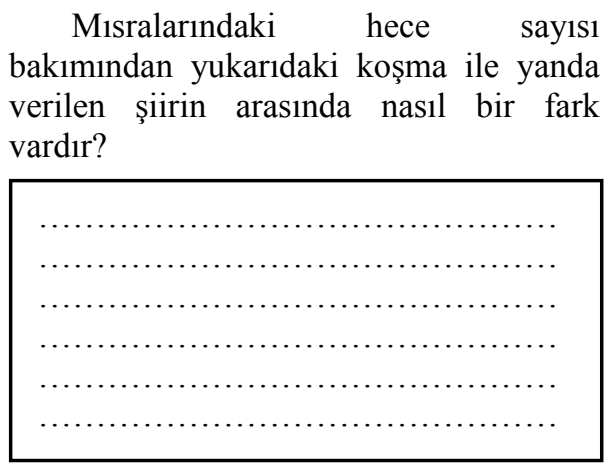

Yapılabilecek benzer etkinlikler 2015 Türkçe Öğretim Programında "Şiirde kafiye, redif gibi ahenk unsurları fark ettirilir, bunların türüne değinilmez", "Serbest şiire ve hece ölçüsüne değinilir. İstiklal Marşı'nın aruz ölçüsü ile yazıldığı belirtilir ancak aruz ölçüsü bilgisine girilmez" açıklamalarının bulunduğu 7. sınıf kazanımlarında "Şiirin şekil özelliklerini bilir" kazanımını karşılamaya yönelik olarak kullanılabilir. Öğrencilere benzer 
bir etkinlik ile bu kazanım doğrultusunda redif, kafiye gibi şiirin ahenk unsurları ile serbest şiir ve hece ölçüsü arasındaki fark hissettirilebilir.

\section{DEMİRCİ MEHMET EFE TÜRKÜSÜ}

Demirci de Mehmet Efem de geliyor, açılsın yollar

Sıralanmış da koçyiğitler, kaçılsın dağlar

Yürü bre Demirci de Mehmet Efem dağlar yürüsün,

Hainleri, düşmanları korku da bürüsün.......

Böylesi yürek nasip olmaz, olmaz her kula

Karıncalı Dağları da neler söyler bir gelse dile, bir gelse dile

Nazilli'nin dağları da neler söyler bir gelse dile, bir gelse dile....

Bas mavzerin tetiğine de cihan titresin

Düşmesin türkün dillerden namın bitmesin, namın bitmesin.......

Örnek Etkinlik 5:

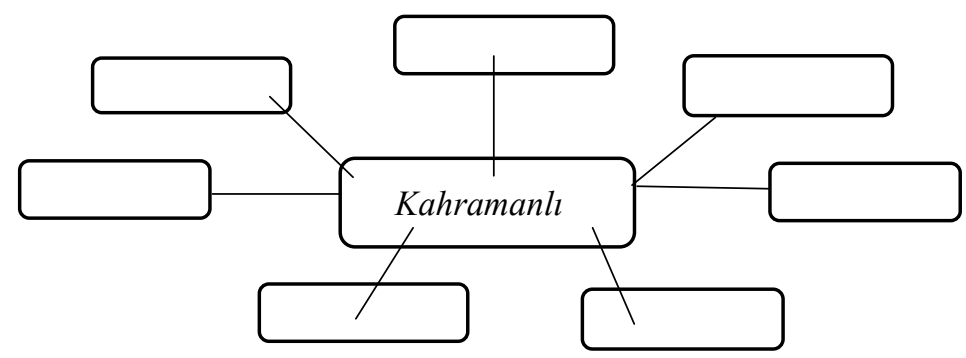

Kavram haritası veya benzer etkinlikler 2015 Türkçe Öğretim Programı'nda 8. Sınıf kazanımlarından alan "Anlamını bilmediği sözcük ve sözcük gruplarının anlamını belirler." ve "Okuduğu metindeki sözcük ve sözcük gruplarının cümle içinde kazandığı anlamı fark eder.” kazanımlarını karşılamaya yönelik olarak kullanılabilir.

\section{Örnek Etkinlik 6:}

"Yürü bre Demirci de Mehmet Efem dağlar yürüsün"

"Bas mavzerin tetiğine de cihan titresin"

Yukarıdaki altı çizili ifadelerde nasıl bir anlatıma başvurulmuştur?

Kişileştirme ve abartma sanatları anlatıldıktan sonra öğrencilerin yukarıda verilen cümlelerdeki abartma ve kişileştirme sanatlarını belirlemeleri istenir. Yapılabilecek benzer etkinlikler 2015 Türkçe Öğretim Programı'nda “Benzetme, kişileştirme, konuşturma, zıtlık, abartma söz sanatları verilir" açıklamasının yer aldığı 8. sınıf kazanımlarından "Okuduklarındaki söz sanatlarını bulur." kazanımını karşılamaya yönelik olarak kullanılabilir. 


\section{Örnek Etkinlik 7:}

"Demirci Mehmet Efe Türküsü” ile yanda verilen şiirin konuları, ana fikirlerini ve şiirlerdeki ana duyguyu yazınız. Bu iki şiir arasında nasıl bir fark olduğunu ifade ediniz.

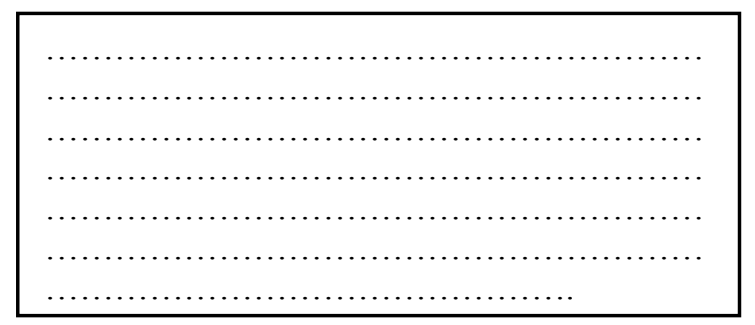

Sonbahar geliyor serçe

Yuvanı ne yapacaksın?

Meyvelerin içi geçecek

Rüzgar başka çeşit esecek

Yağmurlarla 1slanacaksın.

Cahit KÜLEBİ

Benzer bir etkinlik ile 2015 Türkçe Öğretim Programı'nda 8. Sınıf kazanımlarında yer alan "okuduklarının konusunu ve ana fikrini/ana duygusunu belirler" kazanımı ile "şiirin tür ve şekil özelliklerini bilir” kazanımı karşılamaya yönelik olarak bir etkinlik yapılabilir. Bununla birlikte farklı türdeki şiir örneklerine yer verilebilir.

\section{Örnek Türkülerde Değerler Aktarımı Bakımından Yer Alan Öğeler}

İnsanlar duyu organları ile kavradıkları varlıklara duygusal olarak sahip oldukları izlenimler doğrultusunda bir önem verirler. Duygusal olarak sahip olunan bu izlenimler "değer" olarak adlandırılmaktadır (Yeşil ve Aydın, 2007: 66). Değerler, nelere önem verilmesi, nelerin tercih edilmesi gerektiğini belirtmektedir. Eğitim kurumları da öğrencilere tercih edilmesi, önem verilmesi gereken değerlerin neler olduğunu ve bu değerlerin hangi davranışlarla, nasıl gerçekleştirilebileceği konusunda rehberlik eden kurumlardır (Akbaş, 2008: 10). Türkçe Öğretim Programı öğrencilerin temel dil becerilerini ve zihinsel becerileri kazanmaları ile bireysel ve sosyal yönden gelişebilmeleri sağlamaya imkan sunan, temel dil becerilerini edinmelerini sağlayacak bilgi beceri ve değerleri içeren bir bütünlük içinde yapılanmıştır (MEB, 2015: 3). Bunun yanında 2015 Türkçe Öğretim Programı'nın genel amaçlarından biri “Türk ve dünya kültür ve sanatına ait eserler aracılığıyla milli ve evrensel değerleri tanımalarını sağlamaktır" olarak ifade edilmiştir (MEB, 2015: 5). İncelenen türkülerde yer alan değerler aşağıda açıklanmıştır.

\section{“Çanakkale Türküsü” nde Yer Alan Değerler}

\section{Kahramanllk/Cesaret}

Çanakkale Türküsü Türk Tarihinde önemli bir yere sahip olan Çanakkale Zaferi'ni anlatan bir türküdür. $\mathrm{Bu}$ türküde "Ana ben gidiyom düşmana karşı" ifadesi ile vatan savunması için cepheye giden askerlerin cesaretlikleri ifade edilmektedir. Ayrıca bu davranış vatan ve millet sevgisi örneğinin bir göstergesidir. Çanakkale Savaşı hakkında verilecek bilgi ile bu türkü ögrencilere vatan ve millet sevgisini aktarmada etkili olacaktır.

\section{Fedakarlık}

Çanakkale Türküsü'nde “Kimimiz nişanlı kimimiz evli” mısrası ile savaşa giden gençlerin vatan savunması için eşlerini ailelerini bıraktıkları ifade edilmiştir. Ayrıca "Analar babalar umudu kesti" mısrasında da anne ve babaların çocuklarını vatana feda edebildikleri görülmektedir. $\mathrm{Bu}$ fedakarlık örnekleri ile öğrencilerin gerek vatan ve milletlerine karşı gerekse başka insanlara karşı yardım edebilmek amacıyla küçük ya da 
büyük fedakarlıklar yapabilmenin insana katacağı değer ve bu fedakarlıkların yol açacağı olumlu sonuçlar öğrencilere ifade edilebilir. Bununla birlikte, insanların başkalarına yardım etmeleri için yapabilecekleri fedakarlıkların öneminin açıklanması, öğrencilerde "yardımlaşma" ve "dayanışma" değerleri için farkındalık geliştirmelerine de yardımcı olabilir.

\section{“Koşma” da Yer Alan Değerler}

\section{Kalp kırmamak/Vefa}

$\mathrm{Bu}$ şiirde geçen "Hatırdan gönülden geçici olma" ve "Hatıra dokunup yıkıcı olma" mısraları herhangi bir nedenden dolayı bir insanın gönlünü kırmamayı açıklamaktadır.

\section{Saygl}

"Mecliste arif ol kelamı dinle" "El iki söylerse sen birin söyle" misraları ile karşımızda konuşan insanın söylediklerini dinlemeyi ve özellikle fazla bilgi sahibi olmadığımız konularda çok konuşulmaması gerektiği ifade edilmektedir. İnsanları dinlemek, karşıdaki kişiye saygı duyulduğunu gösterirken o kişinin bilgi ve görüşlerinden faydalanılabileceği belirtilmektedir.

\section{Iyilik Etmek}

"Elinden geldikçe sen eylik eyle" "Sen iylik etde o zayi olmaz" mısralarında öğrencilere, insanlara iyilik etmenin önemi vurgulanabilir. Başkalarına karşı yapılan iyilikler ile o insanlara nasıl yardımcı olunabileceği ve yapılan hiçbir iyiliğin karşılıksız kalmayacağı ifade edilerek öğrencilere iyilik etmek, başkalarına yardım etmek konularında farkındalık kazandırılabilir. Ayrıca "Darılıp da başa kakıcı olma" mısrasında iyilik yapılan birinin yüzüne karşı bu iyiliği sık sık söyleyerek o kişiyi zor durumda bırakmanın erdemli bir davranış olmadığı ifade edilerek yapılan iyiliklerin dile getirilmemesinin daha doğru bir davranış olduğu belirtilebilir.

\section{Alçakgönüllü Olmak}

"Alçaklarda otur gözet kendini" "Katı yükseklerden uçucu olma" mısraları ile öğrencilere alçakgönüllüllük kavramı benimsetilebilir. İnsanların başkalarını küçük görerek kendi yaptıklarının ve kendi davranışlarının daha üstün olduğunu düşünmesinin yanlış bir davranış olduğu vurgulanabilir. Böyle bir durumda başkalarının fikir ve görüşlerinden faydalanılamayacağı gibi toplum tarafından sevilmeyen biri olunacağı belirtilebilir.

\section{“Demirci Mehmet Efe Türküsü” nde Yer Alan Değerler}

\section{Cesaret/Kahramanlık/Yiğitlik}

"Demirci Mehmet Efe Türküsü" nde yer alan "Demirci de Mehmet Efem de geliyor, açılsın yollar "Sıralanmış da koçyiğitler, kaçılsın dağlar" mısralarında yiğitlik kavramından söz etmek mümkündür. "Hainleri, düşmanları korku da bürüsün" mısrasında yine yiğitlik, cesaretlik ifadeleri yer almaktadır. Bu türküde vatan uğruna düşmana karşı cesur olmaya vurgu yapılmıştır. Gösterilen cesaretin gerekçesinin vatan savunması olması öğrencilere vatan sevgisini kazandırmakta rol oynayabilecek bir durumdur.

\section{SONUÇ VE ÖNERILER}

Yapılan araştırmada 2015-2016 Eğitim-Öğretim yılında ortaokullarda okutulacak olan ders kitaplarında 3 tane türküye yer verildiği görülmüştür. Bunlardan biri Cem Yayınları Türkçe 5. sınıf ders kitabında yer alan "Sözlü Geleneğimiz" başlıklı metin içinde bulunan "Çanakkale Türküsü” dür. Bu metinde yer alan etkinliklere makalede yer verilmiştir. Bir 
diğeri ise Meram Yayınları Türkçe 7. sınıf ders kitabında yer alan "Kişisel Gelişim" temasında bulunan "Koşma" adlı şiir ile "Sevgi temasında" bulunan "Uçun Kuşlar" şiirilerdir. Bu şiirler bestelenen ve türkü olarak söylenen şiirlerdir. Bu şiirler kitapta serbest okuma metni olarak geçmektedir. Ders kitabında ve öğrenci çalışma kitabında şiirler ile ilgili etkinlikler bulunmamaktadır. "Koşma" adlı şiir ve örnek olabilecek "Demirci Mehmet Efe Türküsü” için 2015 Türkçe Öğretim Programı’nda yer alan kazanımlar doğrultusunda örnek etkinlikler hazırlanmıştır.

Türkülerin, 2015 Türkçe Öğretim Programında yer alan kazanımları gerçekleştirmeye yönelik ürünler arasında olduğu ifade edilebilir. Bunun yanında ele aldığımız türkülerde milli ve evrensel değerlerin yer aldığı görülmektedir. Bu noktadan hareketle türkülerin, söz konusu değerlerin öğrencilere aktarılmasında kullanılabilecek halk ürünleri arasında olduğu söylenebilir.

Türkülerin de içinde bulunduğu Türk halk kültürü ürünleri geçmişten günümüze kadar gelen tarihi ve kültürel birikimin sonucunda oluşmuştur. Her geçen gün unutulma tehlikesi ile karşı karşıya olan geleneğin bir kültür varlığı aracılığıyla gelecek kuşaklara aktarılması önem arz etmektedir; bundan dolayı ders kitaplarında kültürel öğelere yer vermek bu işlevi yerine getirebilecek unsurlar arasındadır.

Türküler ezgili olma özelliklerinden dolayı öğrenmeyi kolaylaştırmaktadır; bu nedenle Ortaokul Türkçe derslerinde konu ve etkinliklerle birlikte türkülerin dinletilmesi öğrencilerin derse olan ilgisini artırması bakımından öğrenme ortamını da olumlu yönde etkileyecektir.

\section{KAYNAKÇA}

Akbaş, O. (2008). Değer Eğitimi Akımlarına Genel Bir Bakış. Değerler Eğitimi Dergisi. 6 (16): 9-27.

Artun, E. (2009). Ortak Türk Kültürü Ürünlerinin Çocuk Edebiyatına Katkıları.turkoloji.cukurova.edu.tr E.T. 20.12.2011.

Artun, E. (1999). Türk Halk Kültürünün Balkanlardaki Rolü. Avrupa'ya İlk Adım Uluslar Arası Sempozyumu Bildiri, Gelibolu.

Aytaş, G. (2003). Türkülerde Turna. Türk Kültürü ve Hacı Bektaş Veli Araştırma Dergisi. 28 Ankara, S. 13-33.

Balta, E. E. (2013). Bilmecelerin Dil-Düşünme Bağlamında Eğitimdeki Yeri ve Önemi. Turkısh Studies. 8 (1): 891-899.

Bulut, M. (2013). Türkçe Eğitimi ve Öğretiminde Dil ve Kültür Aktarımı Olarak Atasözleri ve Deyimlerin Önemi. Turkish Studies. 8 (13): 559-575.

Çangal, Ö. (2012). Yancılara Türkçe Öğretiminde Kültür Taşıyıcısı Olarak Türküler. Gazi Üniversitesi Türkçe Araştırmaları Akademik Öğrenci Dergisi. 2 (2): 9-20.

Demir, N. (2008). Avrupada Yaşayan 0-6 Yaş Grubu Türk Çocuklarına Türkçe ve Türk Kültürünün Öğretilmesinde Kullanılabilecek Bir Materyal: “Türk Ninnileri”. Uluslararası Sosyal Araştırmalar Dergisi. 1 (5): 224-240.

Kurudayığlu, M. (2015). Temel Dil Becerilerinin Kazandırılması Açısından Tekerlemeler. Dil ve Edebiyat Eğitimi Dergisi. 15: 40-62.

M.E.B. (2015). Türkçe Dersi (1-8. Sınıflar) Öğretim Programı. ANKARA. 
Özsoy, B. (2004). Karadenizde Atma Türküler ve Atma Türkü Geleneği. Karadeniz Araştırmaları 3: 113-118

Toker, S. (2011). Türkçenin Anadili Olarak Öğretiminde Ninni ve Tekerlemelerin Yeri. Uluslararast Sosyal ve Ekonomik Bilimler Dergisi. 1 (1): 25-29.

Tüm, G. Ve Sarkmaz Ö. (2012). Yabancı Dil Türkçe Ders Kitaplarında Kültürel Öğelerin Yeri. Hacettepe Üniversitesi Eğitim Fakültesi Dergisi. 43: 448-459.

Vural, F. (2011). Türk Kültürünün Aynası: Türküler. E-Journal of New World Science Academy 6 (3): 397-411.

Yangil, M. K. Ve Kerimoğlu, C. (2014). Bilmecelerin Eğitimdeki Yeri ve Önemi. Eğitim Bilimleri Araştırmaları Dergisi. 4 (2): 341-354.

Yeşil, R. Ve Aydın, D. (2007). Demokratik Değerlerin Eğitiminde Yöntem ve Zamanlama. Türkiye Sosyal Araştırmalar Dergisi. 11 (2): 65-84. 